\title{
Debt Modifications: Tax Planning Options Including New 10-Year Potential Deferral
}

\author{
Ann Galligan Kelley, Providence College, USA
}

\begin{abstract}
With the recent decline in the real estate market, many taxpayers, both individually and/or in partnerships, are seeking to renegotiate the terms of their existing debt instruments. There is some concern though that these debt modifications could lead to possible cancellation of debt $(C O D)$ income with potential tax consequences at a time when affected taxpayers can least afford to pay them. To help alleviate this issue, the American Recovery and Reinvestment Tax Act of 2009 added subsection(i) to Internal Revenue Code Section 108 which gives taxpayers the option to elect to delay recognition of their 2009 or 2010 COD income until 2014 and then include it in income ratably in their 2014 through 2018 calendar tax years. Section 108(a)(1)(B) may still be used by insolvent taxpayers to exclude gross income up to their amount of indebtedness. This paper reviews the options available to taxpayers and gives specific examples under IRC Section 108 to either exclude or defer their cancellation of debt income. It also discusses the potential tax cost for these options and advantages as well as some specific issues pertaining to partnerships. Compliance issues under Rev. Proc. 2009-37 for affected taxpayers is also discussed with the additional potential for taxpayers to elect to defer only part of their COD income.
\end{abstract}

Keywords: Cancellation of debt (COD), Section 108, insolvency exclusion, American Recovery and Reinvestment Tax Act of 1009, Section 108(i) election, deferral of COD Income, Revenue Procedure 2009-37, partial deferral of COD income, indebtedness, discharge of indebtedness (DOI), debt modifications

\section{INTRODUCTION}

$\mathcal{J}$ ax planning is critical for debt forgiveness particularly in a declining real estate market. Section 61(a)(12) of the Internal Revenue Code (IRC) provides that gross income includes income from the discharge of indebtedness. Internal Revenue Code Section 108, however, has provisions that provide for exclusion of cancellation of debt income. Moreover, Section 108(i) of the American Recovery and Reinvestment Tax Act of 2009 was added to provide a new option whereby taxpayers can defer cancellation of debt (COD) income up to five years and then ratably include their COD income over the next five years.

\section{BACKGROUND}

A taxpayer can see hundreds, thousands or even millions of dollars of income postponed and possibly even forgiven forever. Assume what might be a typical scenario in the recent real estate market. Taxpayer John Smith is a 30\% general partner in a partnership which financed a newly constructed office building in 2006 under a $\$ 30$ million recourse mortgage loan. The property is now worth $\$ 14$ million. Workout negotiations have recently resulted in the sale of the office building to an unrelated party for $\$ 20$ million with the $\$ 16$ million balance remaining on the original mortgage forgiven.

Without IRC Section 108, the partners would report $\$ 16$ million of cancellation of debt (COD) income. Hence, taxpayer John Smith would report $\$ 4,800,000$ (\$16 million x 30\%) of COD income. At the ordinary tax rate of $35 \%$, this would result in $\$ 1,680,000$ in federal income taxes without regard to passive loss or other tax carryforwards. 
This scenario could be quite different under Section 108. It is quite possible that this $\$ 16$ million of COD income may be either excluded or deferred as a result of Section 108(a)(1). Section 108(a)(1)(B) provides that gross income does NOT include discharge of indebtedness income if the discharge occurs when the taxpayer is insolvent. If the taxpayer is solvent and not a C Corporation, there is another provision under Section 108(a)(1)(D) that provides for the exclusion of COD income; the basis of depreciable real property, under Section 108(c)(1), would be written down by the amount of the exclusion.

The partnership itself recognizes COD income, and each partner is allocated a distributive share to be excluded or included depending on the individual's circumstances. (Code Secs. 108(d)(6), H. Gershkowitz v Commr, (1987)).

This paper will also discuss a new provision under the American Recovery and Reinvestment Tax Act of 2009 (ARRA) enacted on February 17, 2009 that will give taxpayers with 2009 or 2010 COD income a choice of Sec 108(a) or the ability to elect 108(i), which allows affected taxpayer to take a deferral with income being taken into income over 5 years starting in 2014. It is interesting to note that this new election option (108(i)) is made at the partnership level, which potentially could affect the partners quite differently depending on their tax situation.

\section{EXCLUSION OF COD: INSOLVENCY}

The first step under Section 108(a)(1)(B) is to see if the taxpayer is insolvent. The term insolvent is defined by Section 108(d)(3) as the excess of liabilities over the fair market value of assets determined with respect to the taxpayer's assets and liabilities immediately before the discharge. Hence, it is necessary to prepare a fair market value balance sheet just prior to the discharge of indebtedness. Note that market values rather than book values are used in determining insolvency.

To continue the example discussed above, the original mortgage note was incurred when John Smith and his partners borrowed $\$ 30$ million as recourse debt in order to construct the building at a time when it had a value of more than $\$ 30$ million. Immediately prior to the discharge of indebtedness, John Smith had a 30\% interest in an office building that was valued at $\$ 14$ million. His 30\% pro-rata share of the building's $\$ 14$ million fair value is $\$ 4,200,000$. John Smith's only other asset at this time was his personal home, held jointly with his spouse. This home had a fair market value of $\$ 600,000$. John Smith's only other liability was his nonrecourse mortgage held jointly on his personal home totaling $\$ 450,000$.

Thus, immediately before the cancellation of debt, John Smith's balance sheet based on fair market value was:

\section{ASSETS}

Office building ( $\$ 14$ million $\times 30 \%)$

Personal home $(\$ 600,000 \times 50 \%)$

Total assets

$$
\begin{array}{r}
\$ 4,200,000 \\
300,000 \\
\hline \$ 4,500,000 \\
\hline
\end{array}
$$

\section{LIABILITIES}

Mortgage note - office building (30\%)

$\$ 9,000,000$

Home mortgage note $(50 \%)$

225,000

Total liabilities

$\$ 9,225,000$

EQUITY

Negative net worth

Total liabilities and equity

$\underline{(\$ 4,725,000)}$

$\$ 4,500,000$

As the balance sheet shows, John Smith had a negative net worth of $(\$ 4,725,000)$ immediately before the discharge of indebtedness and hence was indeed insolvent. 
Since John Smith was insolvent immediately prior to the cancellation of indebtedness, he may thus exclude, per Section 108(a)(1)(B), COD income up to the amount of his negative net worth. In our example, John Smith had $\$ 4,800,000$ in COD income $[(\$ 30,000,000$ - $\$ 14,000,000) \times 30 \%]$ and $\$ 4,725,000$ negative net worth. Hence, John Smith may exclude $\$ 4,725,000$ of COD income and report only the balance of $\$ 75,000$ COD income on his personal tax return. At the ordinary tax rate of $35 \%$, his federal tax liability has now been reduced from $\$ 1,653,750$ to $\$ 26,250$.

Rev. Rul. 92-53 provides some insight into this exclusion: "the legislative history underlying the Section 108 insolvency exclusion provides, as a rationale for the insolvency exclusion, that an insolvent taxpayer should not be burdened with current taxation on the discharge of indebtedness to preserve the taxpayer's 'fresh start' resulting from that discharge."

\section{TAX COST FOR THIS EXCLUSION}

The exclusion provided by Section 108(a) is not without a tax cost. Section 108(b) provides that the amount of discharged debt, which is excluded from gross income, is to be applied to reduce certain "tax attributes" of the taxpayer. The "tax attributes" are a series of deductions and credits listed in Section 108(b)(2) as well as the adjusted bases of certain property owned by the taxpayer. The amount excluded under Section 108(a)(1)(A)-(C) is applied to reduce a taxpayer's tax attributes in the following order:

- $\quad$ Any NOL for the taxable year of discharge and any NOL carryforward amount to such year.

- General business credit carryover to or from the taxable year of a discharge used in determining the amount allowable under Section 38.

- $\quad$ Minimum tax credit available under Section 53(h) at beginning of the taxable year immediately following the taxable year of discharge.

- $\quad$ Capital loss carryovers. Any net capital loss for taxable year of discharge and any capital loss carryover to such year.

- $\quad$ Basis reductions via Section 1017.

- $\quad$ Carryover of passive activity losses and credits from the taxable year of discharge.

- $\quad$ Foreign tax credit carryovers.

Section 108 reduces tax attributes to force a taxpayer who benefits from the exclusion to forfeit future tax advantages in return. It is important to note when complying with Section 108(a)(1)(B) that initially one must complete the current year's tax return (i.e. for 2009) utilizing the Section 108 exclusion any existing tax attributes. After the tax return for the current year is complete, then on the first day of the following year (i.e., 1/1/2010), the reduction of tax attributes occurs. (See Section 108(b)(4)(A)).

A taxpayer who has many tax attributes remaining on the first day of the succeeding tax year will not take full advantage of this Code section's exclusion benefit. Instead, his exclusion may, in fact, become a deferral. In order to take full advantage of the exclusion of income, it is wise for a taxpayer to use as many tax attributes as possible in the year of the discharge of indebtedness. Any remaining tax attributes, as itemized above, will be reduced on the first day of the following tax year and therefore lost.

Good tax planning might entail the sale of other assets held by the taxpayer in the same year in which the discharge of indebtedness arises. For example, a sale generating a gain which would be offset by the net operating loss (NOL), thereby utilizing the NOL before the NOL is subsequently reduced.

Section 108 has obviously resulted in significant tax savings. However, as discussed above, there are further tax considerations for John Smith. Returning to the above example, John Smith excluded \$4,725,000 of COD income from his current year's tax return. He must now reduce his tax attributes by this amount but not below zero. Assume that on January 1, 2010, John Smith has a \$1 million net operating loss carryforward, which must now be reduced to zero. The only other tax attribute that John Smith possesses is the basis in his personal home. His pro-rata share of the fair market value of his home is $\$ 300,000$. The pro-rata share of the adjusted tax basis of a home may be less or more than the fair market value. 
Assume the home has an aggregate adjusted tax basis of $\$ 530,000$, John Smith's pro-rate share is $50 \%$ or $\$ 265,000$. Further, as discussed above, John Smith has a mortgage liability of $\$ 225,000$. His excess tax basis on his home over the liability is $\$ 40,000$. ( $\$ 265,000$ pro-rata adjusted tax basis less $\$ 225,000$ pro-rata home mortgage loan $=\$ 40,000)$. Consequently, John Smith will reduce his home's tax basis by $\$ 40,000$ to $\$ 225,000$. His wife's prorate share in the adjusted tax basis of the home remains at $\$ 265,000$. Thus, the total adjusted tax basis of their home is $\$ 490,000$ jointly.

John Smith's balance sheets on the first day of the succeeding tax year (i.e., 1/1/2010) are as follows:

ASSETS

Office building

Personal home $(\$ 600,000 \times 50 \%)$

Total assets

\section{LIABILITIES}

Mortgage note - office building (30\%)

Home mortgage note $(50 \%)$

Total liabilities

Fair Market Value Tax Basis

\begin{tabular}{cl}
0 & 0 \\
260,000 & $\$ 225,000$ \\
\hline$\$ 4,500,000$ & $\$ 225,000$ \\
\hline
\end{tabular}

$\$ 9,000,000$

225,000

$\$ 9,225,000$

$\frac{\$ 225,000}{\$ 225,000}$

$(\$ 4,725,000)$

$\$ 4,500,000$

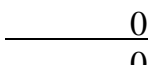

Negative net worth

Total liabilities and equity

*After J. Smith's $\$ 40,000$ reduction of tax basis. (His wife's pro-rata share remains at $\$ 265,000$ ).

In Summary, Section 108(a)(1)(B) allows one who is insolvent to exclude discharge of indebtedness income. This exclusion can be permanent once there are no further tax attributes to write down.

\section{DEFERRAL OF COD}

Section 108(i) of the American Recovery and Reinvestment Tax Act of 2009 can result in considerable tax and cash flow benefits to taxpayers who renegotiate settlements of their debt. Section 108(i) permits taxpayers to elect delayed recognition of their 2009 or 2010 COD income arising from a cancellation, reacquisition, or modification of a business debt until 2014 and then include it in income ratably over a 5-year period. Typical examples of COD income include the restructuring of a bank loan, the repurchase of a bond for less than its face value and an outright forgiveness of a note. Calendar year taxpayers would thus include their COD income at the rate of 20 percent per year for calendar years 2014 through 2018. Taxpayers who are insolvent may also elect to defer income from COD rather than exclude the income and reduce tax attributes by a corresponding amount.

To illustrate Section 108(i), assume that your client, Mary Brown, is a limited partner in a real estate partnership. Ms. Brown holds a 10\% interest in the partnership. The partnership purchased an office building in 2005 with a $\$ 40$ million nonrecourse mortgage. With the recent decline in real estate markets, the building's current fair market value approximates $\$ 22$ million.

The partnership had been on the verge of bankruptcy. Negotiations with a new mortgage lender provided the partnership with a new mortgage loan for $\$ 18$ million. The original mortgage lender accepted the $\$ 18$ million from this loan plus $\$ 3$ million of partnership cash in full satisfaction of the original $\$ 40$ million mortgage. The net result of this transaction created $\$ 19$ million of discharge of indebtedness income. ( $\$ 40$ million original mortgage less $\$ 21$ million [ $\$ 18$ million mortgage $+\$ 3$ million cash] satisfaction.)

Without Section 108, the partners would report $\$ 19$ million COD income. Mary Brown would thus report $10 \%$ or $\$ 1.9$ million. At the ordinary 2009 tax rate of 35\% (expected to be 39\% for 2010), Mary Brown would incur a federal income tax liability of $\$ 665,000$ without regard to passive loss or other tax carryforwards. This scenario can be revised, however, under the application of Section 108(i). In most situations a renegotiation of debt would be 
treated as a reacquisition in accordance with IRC Section Code Sec. 108(i)(4)(B). This example would be quite straight forward if your client owned this office building outside of a partnership. Special rules apply for the allocation of any income deferred under this provision in the case of a partnership.

Passthrough entities, such as partnerships and $\mathrm{S}$ corporations, make the election at the entity level. Hence, the election for Ms. Brown is made at the partnership level. As a 10\% limited partner, Section 108(i)(6) special rule for partnership applies. Any income deferred under this subsection shall be allocated to the partners immediately before the discharge in the manner such amounts would have been included in the distributive shares of such partners if such income were recognized at such time. Any decrease in a partner's share of partnership liabilities as a result of such discharge shall not be taken into account at the time of the discharge to the extent it would cause the partner to recognize gain. Careful tax planning will consider all of the tax consequences and alternatives prior to debt restructuring debt in order for partners to avoid unexpected COD income and any potential negative cash flow resulting from unexpected tax consequences.

If Mary Brown's partnership elects Section 108(i), the partnership will defer their \$19 COD income until 2014. As a $10 \%$ limited partner, Ms. Brown will thus report $\$ 380,000$ of COD income $(\$ 19$ million x $10 \%=\$ 1.9$ million x 20\% per year) each year for calendar year 2014 through 2018 rather than reporting \$1.9 million income during the 2009 taxable year.

Consensus among government representatives at New York University's $68^{\text {th }}$ Annual Institute on Federal Taxation in New York on October 21, 2009, was that Congress assigned the election to be at the partnership level in part out of concern that a single reporting entity, the partnership, would be more likely to keep track of their obligation to report COD income than multiple partners. (Federal Tax Day 2009). Although partnerships make the election at the entity level, it should be noted that under Rev. Proc. 2009-37 Section 4.04(1) allows some flexibility since some partners may benefit from deferral while other partners may welcome income if they are able to offset it immediately. Hence, Rev. Proc. 2009-37 allows for a partial election. The partnership is thus able to decide through allocation which partner(s) get the deferral under Section 108(i). The deferred income on the portion of the debt subject to the 108(i) election is allocated to the partner(s) who want the deferral. Immediate COD income can be allocated to and recognized by other partner(s) who might perhaps benefit from Section 108(a) exclusion. Hence, if a partnership has two equal partners (one insolvent and one solvent) and \$1 million of COD income, it could allocate to apply Code Section 108(i) to $\$ 500,000$ of the COD income with that amount being allocated to the solvent partner so that this partner has a deferred amount and allocate the remaining $\$ 500,000$ to the partner who would benefit from the Section 108(a) exclusion. This would permit said insolvent partner to take advantage of the exclusion of COD with the write down of tax attributes beyond his insolvent amount.

\section{COMPLIANCE}

In reporting this information to the IRS with regard to Code Section 108(a) [insolvency exclusion and write down of tax attributes], one needs to complete IRS Form 982, "Reduction of Tax Attributes Due to Discharge of Indebtedness".

When to File. Form 982 should be filed with the client's original income tax return for the tax year in which the discharge of indebtedness was obtained. Failure to file this form with the original return can be rectified by filing an amended return within six months of the due date of the return (excluding extensions). Write "filed pursuant with Section 301.9100-2" on the amended return.

Specific Instructions. This tax form consists of only three parts. Part I relates primarily to identifying the discharge of indebtedness. If a client per Section 108(a)(1)(B), such as John Smith in our example, were insolvent just prior to the discharge of indebtedness, he would check off Part I(b), "Discharge of Indebtedness to the extent insolvent."

Part II of the form covers the reduction of tax attributes. Part III would only apply to a corporation, which is not the case in our examples. The total amount of discharged indebtedness excluded from gross income goes on Line 2 of Part I. It would be helpful at this point to walk through Form 982. 
John Smith. This taxpayer in the first example has $\$ 4,800,000$ of discharge of indebtedness income. His negative net worth just prior to the discharge of indebtedness was $\$ 4,725,000$, which can be excluded under Section 108(a)(1)(B). Hence, he has $\$ 75,000$ of taxable income. However, as previously discussed, the amount excluded under Section 108 is applied to reduce tax attributes. John Smith's only tax attributes per Section 108(b)(2) are his:

Net operating loss carry forward

$\$ 1,000,000$

Excess home net basis

$40,000^{*}$

Total Tax attributes

$\$ 1,040,000$

*. $(\$ 265,000$ pro-rata adjusted tax basis less $\$ 225,000$ pro-rata home mortgage loan $=\$ 40,000)$.

On Form 982 John Smith would enter $\$ 4,725,000$ on Line 2 (Part I) for the total amount of discharged indebtedness excluded from gross income. He would then go to Part II to reduce his tax attributes up to the amount of his COD income. John Smith has $\$ 1,040,000$ of tax attributes to be reduced on the first day of the new tax year (i.e. $1 / 1 / 2010)$.

Unfortunately, John Smith was not able to use up these tax attributes in the year of the discharge of indebtedness before they were lost. Hence, his exclusion of \$4,725,000 COD income will cost him \$1,040,000 in tax attributes. On January 1, 2010, John Smith will no longer have any tax attributes. Better tax planning might have averted this problem by accelerating his income in 2009. Had he been able to take other gains and reduce his tax attributes before January 1, 2010, he would not have lost his net operating loss. His net operating loss carryforward has now been reduced to zero.

John Smith would enter on Part II, Line 6, his $\$ 1,000,000$ net operating loss, which is a tax attribute to be reduced. His $\$ 40,000$ of excess basis (aggregate basis in asset over aggregate liability) in his home would be entered on Line 10 of Part II. John Smith should also attach a statement to his Form 982 describing the source of his COD income which was the flow-through from his partnership investment and the partnership's cancellation of indebtedness. He would indicate that he had $\$ 4.8$ million of COD income of which $\$ 4,725,000$ was excluded due to insolvency. Furthermore, it should state that he has reduced all of his tax attributes. Those tax attributes are less than the amount of his COD exclusion as shown on Line 2.

Overall, John Smith has recognized $\$ 75,000$ of taxable income, has deferred $\$ 1,040,000$ income (by using his $\$ 1,000,000$ net operating loss carryforward and write down of home's $\$ 40,000$ excess tax basis), and has excluded $\$ 3,685,000$ (\$4,725,000 less $\$ 1,040,000$ loss of tax attributes) of income by using Section 108(a).

Mary Brown. In the second example, Ms. Brown has \$1.9 million of COD income. If her partnership elected to allocate income to Section 108(i), this taxpayer would report $\$ 380,000$ of COD income ( $\$ 1.9$ million x 20\% per year) each year for calendar year 2014 through 2018 rather than reporting \$1.9 million income during the 2009 taxable year.

\section{COMPLIANCE}

The pass-through entity (partnership) makes the 108(i) election. Partnerships and S corporations making a Code Sec. 108(i) election must report certain Code Sec.108(i) information for each partner and shareholder on the applicable Schedule K-1 filed for the tax year in which the election is made and must provide an election information statement to each partner and shareholder.

\section{WHEN TO FILE \& SPECIFIC INSTRUCTIONS}

A taxpayer that makes a Section 108(i) election must attach a statement meeting the requirements of Rev. Proc. 2009-37, Section 5.02, to its federal income tax return for each tax year beginning with the tax year following the tax year for which the taxpayer makes the election and ending with the first tax year in which all items deferred under Code Sec. 108(i) have been recognized. 
Rev. Proc. 2009-37 specifies in Section 4.07(2) that the partnership must attach to the Schedule K-1 (Form 1065 or Form 1065-B) provided to each partner for the taxable year in which the $\S 108$ (i) election is made a statement satisfying the requirements of this Section 4.07(2). The partnership should not attach these statements to the Schedules K-1 that are filed with the Service, but must retain these statements, and each partner must retain that partner's statement, in their respective books and records. The statement should meet the basic requirements spelled out in section 4.07(2) starting with "Section 108(i) Election Information Statement for Partners" across the top. It should clearly identify the debt instrument to which Section 108(i) applies and specific information pertaining to each partner's deferred and included amounts among other requirements. The statement must include the amount of income to which §108(i)(1) applies and other information the Service may prescribe. Once made, a $\S 108(\mathrm{i})$ election is irrevocable and, except as provided in section 7 of this revenue procedure, may not be modified.

\section{CONCLUSION}

It is interesting to note the difference between Section 108(a)(1)(B) exclusion of COD income and Section 108(i) deferral of COD income. If a taxpayer is insolvent (Section 108(a)(1)(B)) prior to the COD income and his tax planning were done correctly, it is possible that he could exclude this income forever. Wise planning would require, however, that the taxpayer use as many tax attributes as possible in the year of the discharge of indebtedness. If these are not used, these tax attributes will be reduced and lost on the first day of the succeeding tax year. However, one can see some justification for this. If the taxpayer were insolvent prior to the discharge of indebtedness, imposing a tax would be an undue hardship. It is important to note that the exclusion of COD income under Section 108(a)(1)(B) is not elective for the taxpayer. The taxpayer is either insolvent or is not.

The new addition of section 108(i) to the Code is significant because it can permit solvent taxpayers to renegotiate the terms of their debt without the risk of generating COD income at a time when cash flow issues are a concern. A solvent taxpayer could elect Section 108(i) and defer COD income for essentially a ten-year window of time. Electing Section 108(i) permits taxpayers to delay recognition of their 2009 or 2010 COD income until 2014 and then include it in income ratably (20\% per year) in their 2014 through 2018 calendar year tax returns. Deferral can be equated to an interest-free loan from the government. One is simply delaying the eventual payment of taxes; the present value of taxes paid in the future is smaller when compared to the tax liability at the present time on COD income without this tax deferral. Developers, real estate investors and their accountants should be familiar with the workings of Code Section 108. Overlooking this section could be a very costly mistake.

\section{AUTHOR INFORMATION}

Ann Galligan Kelley, CPA is an Associate Professor of Accounting at Providence College. She has a CAGS in Taxation from Bryant College and an MBA from Northeastern University. Formerly in public accounting and private, she also served as a tax accountant for a large law firm and has published articles in various practitioner and academic journals.

\section{REFERENCES}

1. $\quad$ IRC Section (IRC) 61(a)(12)

2. American Recovery and Reinvestment Tax Act of 2009 (ARRA) enacted on February 17, 2009

3. IRC Section 108

4. IRC Section 108(a)(1)

5. IRC Section $108(a)(1)(b)$

6. IRC Section $108(a)(1)(d)$

7. IRC Section 108(c)(1)

8. $\quad$ IRC Section 108(d)(6)

9. H. Gershkowitz v Commr, 88 TC 984, Dec. 43,857 (1987).

10. American Recovery and Reinvestment Tax Act of 2009 (ARRA)

11. IRC Section 108(i)

12. Section 108(d)(3)

13. Rev. Rul. 92-53 
14. IRC Section $108(b)$

15. IRC Sections 108(a)(1)(A)-(C)

16. IRC Section 108(b)(4)(A)

17. IRC Section 108(i)(4)(B)

18. IRC Section 108(i)(6) Special rules for partnerships

19. Federal Tax Day. M.2Government Officials Discuss Hot Partnership Issues; Guidance Coming on Code Sec. 108(i). (Oct. 22, 2009)

20. Rev. Proc. 2009-37, IRB 2009-36, Aug. 17, 2009.

21. Rev. Proc. 2009-37 Section 4.04(1)

22. IRS Form 982, "Reduction of Tax Attributes Due to Discharge of Indebtedness".

23. IRC Section 108(b)(1)

24. IRC Section 108(b)(2)

25. Rev. Proc. 2009-37, Section 5.02

26. Rev. Proc. 2009-37, Section 4.07(2) 